\title{
The Global Distribution of Adventists and Mormons in 2007
}

\author{
DANIEL REEVES \\ Charles University in Prague, Faculty of Science, \\ Department of Social Geography and Regional Development
}

\begin{abstract}
This research explores and compares the worldwide spatial distribution of two relatively young and, in many ways, similar Christian churches, the Seventh-day Adventist Church and the Church of Jesus Christ of Latter-day Saints. I explore the respective churches' distributions and seek explanations for differences between them, in light of the spatial distribution of the world's total population, by considering the origins of both Christian denominations as well as policies and practices that shaped their international diffusion. The findings of this research demonstrate the role of religion in processes of globalization and give a unique, comparative look at two dynamic and increasingly influential religious communities.
\end{abstract}

Key words: Adventists - diffusion - geography of religion - Mormons

\section{Introduction and research questions}

In recent decades, sociologists have paid increased attention to topics concerning religion. Such researchers recognize that secularization theory, rooted in the ideas of Max Weber and other early sociologists, which states that religion should continue to decrease in significance during the modern era, has not proven itself to be completely accurate (Henkel 2006). Religion, religious practices and religious organizations continue to impact - to varying degrees - social and cultural processes in modern societies.

The Seventh-day Adventist Church (Adventists) and the Church of Jesus Christ of Latter-day Saints (Mormons) represent two dynamic Christian groups that have experienced substantial growth since their inception in the nineteenth century. While the fact that this growth has not been uniform in time or space for either of these denominations is not surprising, their differing international distributions tell very different tales of diffusion and can aid in our understanding of rapidly growing religious groups and their social influences.

Two central questions form the backbone of this research: 
- How have Adventism and Mormonism developed and spread from similar beginnings to become international organizations and how do global distributions of Adventists and Mormons compare?

- What denominational characteristics and historical developments help in explaining these churches' unique global distributions?

\section{Literature review}

While scientists and the general public, for that matter, often recognize something of a conflict between science and religion, the truth that religion has played and continues to play significant roles in societies throughout the world is undeniable. Nonetheless, religion and its myriad influences in social networks, in terms of time and space, are frequently overlooked. As Kong (2001, p. 212) states: "In many instances, in the same breath that race, class and gender are invariably invoked and studied as ways by which societies are fractured, religion is forgotten or conflated with race." Religion not only merits inclusion as a criterion for understanding social relations and societies, in general; its omission as an 'axis of identity' along with race, class, nationality and gender (Brace, Bailey and Harvey 2006) is a mistake.

Although geographic research on religion has been conducted for several decades, a number of social scientists regard such research as being sporadic, thematically divergent and unorganized. ${ }^{1}$ Kong (2001) refutes claims that geographic research on religion lacks coherence and is in a state of disarray and provides a detailed and organized review of such research during the 1990s. She frames this review around "politics and poetics in modernity," demonstrating how religion impacts societies and individuals in both secular (political) and spiritual (poetic) ways (Kong 2001, title).

Iannaccone (1997, title) proposes using rational choice theory as a "framework for the scientific study of religion". He develops the rationale of this framework by perceiving a religious "market", in which various religious organizations and movements present their ideological and spiritual "products" to consumers - the general public. Iannaccone's rational choice framework rests on three distinct assumptions:

- Assumption 1: Individuals act rationally, weighing the costs and benefits of potential actions, and choosing those actions that maximize their net benefits.

- Assumption 2: The ultimate preferences (or 'needs') that individuals use to assess costs and benefits tend not to vary much from person to person or time to time.

The same could be said of many post-modernist approaches and sub-disciplines. 
- Assumption 3: Social outcomes constitute the equilibria that emerge from the aggregation and interaction of individual actions. (Iannaccone 1997, p. 26)

I must admit that, as a religious individual, I struggled initially with the idea of applying economic theory to religion and that I still disagree with the underlying philosophy of such an application, which seems to overlook both the existence and importance of divine truth. Rational choice theory also overlooks or minimizes significant personal influences such as family traditions, reluctance to change and any potential social costs of a change in religious affiliation. However, I appreciate the way that this framework provides a foundation for investigating certain aspects of religious participation. Iannaccone's framework is useful, for instance, in attempting to explain the growth and diffusion of religious movements (i.e. by allowing them to be viewed as products or innovations in a "religious" market) or in describing the effects of competition among churches for new members (religious "consumers"). (Iannaccone 1997, see also Iannaccone 1998, Iannaccone and Stark 1997)

Otterstrom has conducted in-depth research on the diffusion of Mormonism throughout the world (1994) as well as on recent developments concerning the Mormon population within the United States of America (2008). He discusses the growth and international development of the Church of Jesus Christ of Latter-day Saints in great detail with strong theoretical and methodological frameworks. His work on worldwide Mormon diffusion highlights increasing growth in developing areas and among groups in challenging economic circumstances (Otterstrom 1994). Focusing on the USA, Otterstrom (2008) demonstrates that, from 1990 to 2004, more rapid growth of Mormonism occurred in the central and eastern United States than in the American West, where it could be said that the market is more saturated.

While I found many references to Mormons and numerous articles focusing partially or entirely on the Church of Jesus Christ of Latter-day Saints (e.g. Dunn 1996, McBride 2007, Iannaccone and Stark 1997, Otterstrom 1994 and 2008), I was not as successful in finding articles focusing entirely on Adventists or the Seventh-day Adventist Church, with the exception of an article on the Adventists' NEW START Program, which included additional references to articles concerning the health benefits of the Adventist lifestyle (Slavíček et al. 2008). ${ }^{2}$ I suspect that this apparent increased availability of social science research on Mormons is due, in part, to the churches' relative sizes in North America, where Mormons outnumber Adventists by more than five to one, and, in part, to the existence of a distinct Mormon culture region in the western United States (see Warf and Winsberg 2008; Zelinsky 2001).

The NEW START Program outlines Adventist practices concerning physical and spiritual health and, according to this article, can effectively reduce the risks of cardio-vascular disease (Slavíček et al. 2008). 


\section{A closer look at Adventists and Mormons}

The Seventh-day Adventist Church and the Church of Jesus Christ of Latter-day Saints exhibit a number of similarities that make comparison of the two organizations both meaningful and interesting. In terms of worldwide membership in 2007 and the place and time of their origin (see Table 1), the churches, indeed, appear very similar. As self-proclaimed Christian churches, Adventists and Mormons also share similar views concerning a number of fundamental beliefs and practices, such as baptism by immersion, only after a candidate has reached a recognizable "age of accountability" ( 8 years old for Mormons, 12-15 years old for Adventists). Both churches place strong emphasis on maintaining a healthy lifestyle and on strengthening marital and family relations, as well as on sharing their beliefs with others through active evangelizing and missionary programs.

Tab. 1 Summary of significant similarities between the Seventh-day Adventist Church and the Church of Jesus Christ of Latter-day Saints

\begin{tabular}{|l|c|c|}
\hline & Seventh-day Adventist Church & $\begin{array}{c}\text { Church of Jesus Christ } \\
\text { of Latter-day Saints }\end{array}$ \\
\hline Place of establishment & $\begin{array}{c}\text { New Hampshire, New York, } \\
\text { Vermont and Michigan, USA }\end{array}$ & New York, USA \\
\hline Time of establishment & $1831-1863$ & $1820-1830$ \\
\hline Worldwide membership 2007 & $15,660,347^{*}$ & $13,193,999^{* *}$ \\
\hline
\end{tabular}

* $145^{\text {th }}$ Annual Statistical Report -2007 . General Conference of Seventh-day Adventists

** Statistical Report: $178^{\text {th }}$ Annual General Conference

In his book Nová náboženská hnutí a jak jim porozumět [New religious movements and how to comprehend them], author Zdeněk Vojtíšek, a researcher whose areas of expertise include new religious movements and the Czech religious scene, describes both of these churches as representatives of a so-called "Christianity of the last days." This is one of three broad divisions that Vojtíšek makes among newer, Protestant Christian churches (the other two divisions are Pentecostal churches and more radical, new Christian movements). The defining characteristics of Vojtíšek's classification include an independence from previously established churches and a focus on preparing for Jesus Christ's return to the earth, as prophesied in scripture (Vojtíšek 2007).

Whether in terms of the Adventist position, advocating a return to thoroughly studying and correctly understanding the Bible, as well as their unique role as the "remnant church;" or through Mormon claims of a "divine restoration of truth," both churches view themselves as the only existing fellowship of true followers of Jesus Christ. Over the years, Adventists and Mormons have moderated their positions slightly and both churches are now quick to recognize and respect the good wrought by and the true principles (according to their respective beliefs) taught by other religious groups, particularly other Christian churches (see www.adventist. org and www.lds.org). 
A closer look at the doctrinal beliefs of these churches (e.g. Rosten 1963), reveals that both are indeed not only looking forward to the second coming of Jesus Christ, but also seeking to prepare the world and its inhabitants for this event, through active evangelizing or missionary efforts. Understanding the history and development of the missionary efforts - and successes - of Adventists and Mormons as well as the churches' similar beginnings (in terms of time and place), in nineteenth-century America, is fundamental in evaluating, explaining and contrasting the global distribution of Adventists and Mormons, today. I will continue by chronologically (Mormons first) describing the origins of the two churches in question. Details concerning missionary efforts and successes will appear later, alongside data on the contemporary worldwide distributions of Adventists and Mormons. ${ }^{3}$

\section{The Church of Jesus Christ of Latter-day Saints}

In 1820, religious excitement had reached a fever pitch in rural New York, in an area and time period later described as the "burned-over district," in reference to the way a surprising variety of religious revivals swept through the area and excited its inhabitants (see Cross 1950). Joseph Smith, Jr., 14 years old at the time, described the religious excitement as follows:

"Some time in the second year after our removal to Manchester, there was in the place where we lived an unusual excitement on the subject of religion. It commenced with the Methodists, but soon became general among all the sects in that region of country. Indeed, the whole district of country seemed affected by it, and great multitudes united themselves to the different religious parties, which created no small stir and division amongst the people, some crying, 'Lo, here!' and others, 'Lo, there!' Some were contending for the Methodist faith, some for the Presbyterian, and some for the Baptist."

"My mind at times was greatly excited, the cry and tumult were so great and incessant. The Presbyterians were most decided against the Baptists and Methodists, and used all the powers of both reason and sophistry to prove their errors, or, at least, to make the people think they were in error. On the other hand, the Baptists and Methodists in their turn were equally zealous in endeavoring to establish their own tenets and disprove all others (The Pearl of Great Price, p. 48)."

Shortly thereafter, Joseph Smith prayed to ask God for direction, concerning which church was the correct one. According to Smith's story and according to the doctrine of the Church of Jesus Christ of Latter-day Saints, God the Father and Jesus Christ visited Smith, in a forested area near Palmyra, New York, and called him

The Jehovah's Witnesses represent another church organization that closely matches these criteria. However, due to difficulties in obtaining statistical data and the somewhat reclusive nature of Jehovah's Witnesses, I have focused entirely on the two churches specified. 
to be a prophet. They instructed Smith, through many additional revelations, on how to organize, or according to Mormon doctrine: how to restore, the Church of Jesus Christ for a final dispensation that would precede Christ's second coming. Mormons also believe that God instructed Joseph Smith on where to find an ancient record - written on thin metal plates - of a people who lived in the Americas from about 600 B.C. to approximately 400 A.D. These people, who according to Mormon tradition are ancestors both to American Indians and Pacific Islanders, worshipped God in accordance with Jewish traditions before the time of Christ and as Christians after Christ's ministry. This record has been published as The Book of Mormon: Another Testament of Jesus Christ and Mormons view it as an additional book of scripture, in essence, an equal companion to the Bible.

The Book of Mormon was first published in 1827 and the Church of Jesus Christ of Latter-day Saints was officially organized with six members on 6 April 1830, in Fayette, New York.

\section{The Seventh-day Adventist Church}

The Adventist movement has its roots in the 1830s and 1840s, mainly in New Hampshire and upstate New York. Preachers and ministers from several contemporary, Christian churches contributed to the emergence of the Seventh-day Adventist Church as we know it today. They rallied around theological ideas, surrounding the imminent return of Jesus Christ ("the literal soon advent of Christ") to the earth and the importance of studying and comprehending the Bible. (http://www.adventist.org/world_church/facts_and_figures/history/index.html.en)

One of the central figures in Adventism's "genesis" story is William Miller. Miller, a veteran of the War of 1812, began to study the Bible in depth to put to rest certain concerns he had with what others called contradictions within the Bible itself. Eventually, he resolved all of his concerns and in doing so became very interested in Biblical prophesies, specifically from Old Testament prophet Daniel, concerning Christ's return to the earth. He spent considerable time calculating the date of Jesus Christ's "second coming". His friends became interested in his studies and encouraged him to preach and proclaim this message to others. Miller began preaching in 1831 and with the help of Joshua Himes, a preacher who acted as something of a public relations specialist, he soon generated a following, known as Millerites. The Millerites enthusiastically expected Jesus Christ to return to earth in glory, sometime during 1843. This expected time of arrival was later adjusted to the spring of 1844 and finally to October 22, 1844. (Vandeman 1986; see also: http://www.whiteestate.org/pathways/pioneers.asp)

A "great disappointment" resulted when Jesus Christ did not return to earth, as predicted, and the Millerites along with other Adventists (at this time, a general term for believers from many faiths including Baptists, Presbyterians, etc.) returned to diligently studying the Bible and preparing for Christ's return, without 
necessarily setting a date for this anticipated event. The preachers and members of several congregations - mainly from various Baptist churches and the Christian Connection Church - continued calling themselves "Adventist" and by 1863, when the Seventh-day Adventist Church was officially organized, it included approximately 3,500 members and 125 churches. (http://www.adventist.org/world_church/ facts_and_figures/history/index.html.en)

Ellen White, whom Adventists recognize as one who had a prophetic gift, was another important figure in the development of Adventism. White attended William Miller's sermons and became converted to the principles he advocated. After the great disappointment discussed above, she played a significant leadership role in keeping the Adventist movement alive. In particular, White was a central figure in the decision to worship on Saturday and not Sunday. Similar to Mormon prophet Joseph Smith, Ellen White also claimed to receive special communications from God for a larger community of believers. She wrote many books, focusing special attention on health and harmony in life, principles that are fundamental to modern Adventism. (http://www.whiteestate.org)

\section{Null Hypothesis and Methods}

In light of their similar beginnings - in terms of time and location - and based on the rational choice theory of economics as applied to religious organizations (see Iannaccone 1998), I propose something of a null hypothesis:

- All other factors being equal, it is supposed that the modern-day global distribution of the Seventh-day Adventist Church and the Church of Jesus Christ of Latter-day Saints - the result of processes of diffusion of the religious "product" of the respective churches - will be identical.

I realize that such a hypothesis seems more than a little absurd and I intentionally include the words "all other factors being equal", knowing that such is not the case. The messages of the respective churches differ, as do the personalities, attitudes and preferences both of those sharing the message and any who would potentially accept it. Nonetheless, this null hypothesis provides a basis for further examination of global distributions of Adventists and Mormons. A significant portion of the explanation of the data and maps presented shall focus on the reality that "all other factors" are not equal and that strong personalities, leaders, administrative decisions and societal attitudes, among other factors, have played and continue to play important roles in the diffusion of Adventism and Mormonism.

Recently Michael Gastner and Mark Newman described a "diffusion-based method for producing density-equalizing maps", which distorts the size of various territories in a defined area to compare a given quantitative variable from territory to territory. In essence, the method is based on the physical principle of linear diffusion and changes the size of each defined territory on a map, according to the 
value of a selected variable. (Gastner and Newman 2004; Barford and Dorling 2007)

With membership data for 2007, provided by the Adventist and Mormon churches themselves, and population estimates for 2007 from the World CIA Factbook, I have utilized this method to generate cartograms that show relationships concerning total population, Adventist population and Mormon population among the various countries of the world. In looking at these cartograms it is helpful to remember that countries, which appear abnormally large, exhibit a relatively high level of the variable being tested, while countries, appearing smaller than they normally would, are home to a relatively low level of the variable in question.

It is also important to note that the relative size of any given territory can only be effectively compared with other territories in the same cartogram. Comparisons between different cartograms are useful in recognizing and contrasting the spatial patterns of the various variables independently, but should not be considered reliable in assessing or comparing the actual values of the variables examined in the different cartograms. For example, the size of Peru in Figure 1, which depicts total population by country, represents over twenty-eight million people, while Peru's size in the Adventist cartogram (Figure 2) - in spite of the fact that it is considerably larger - represents less than 800,000 people.

\section{Discoveries}

With these principles in mind, the cartograms become an interesting tool in visualizing and comparing present distributions and considering the historic diffu-

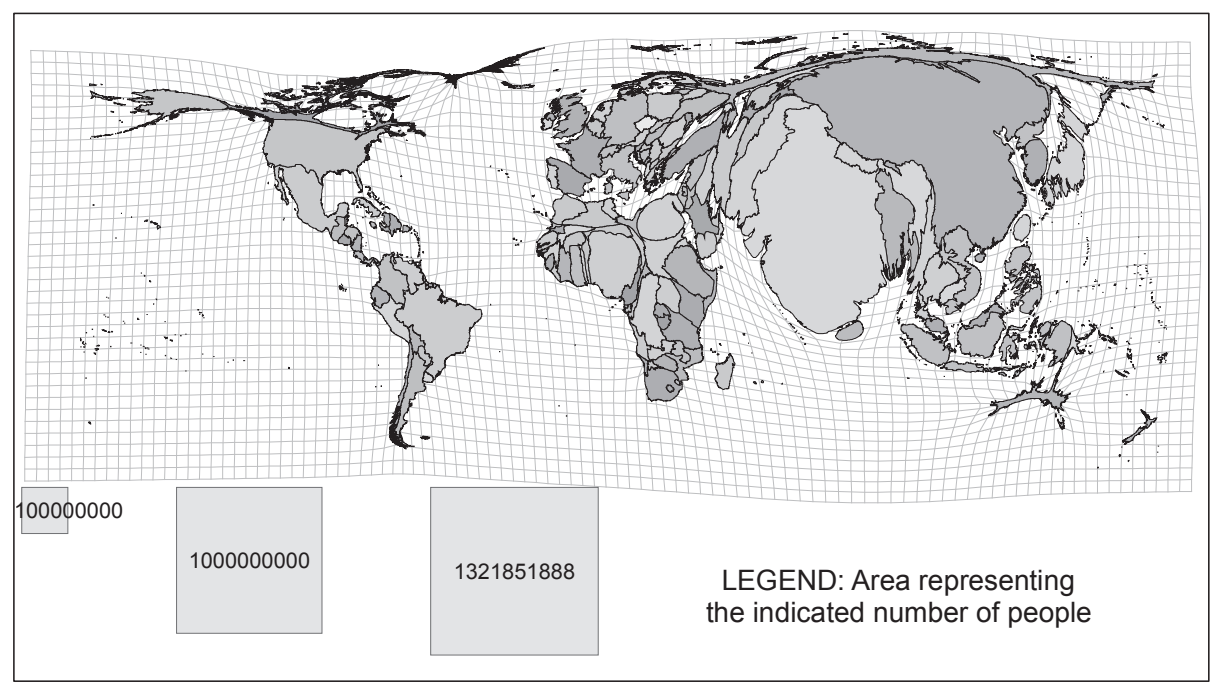

Fig. 1 World population estimates for 2007 by country Source: CIA World Factbook. 
sion of Adventism and Mormonism (Figures 2 and 3), on a global level, in light of total population (Figure 1).

While it can be said of both of these churches that they are international organizations, it is very clear from these cartograms (see Figures 2 and 3) that the Seventh-day Adventist Church has a more balanced international membership than does the Church of Jesus Christ of Latter-day Saints. Adventists have spread into Africa, India, Central Asia and the Caribbean to a significantly higher degree than

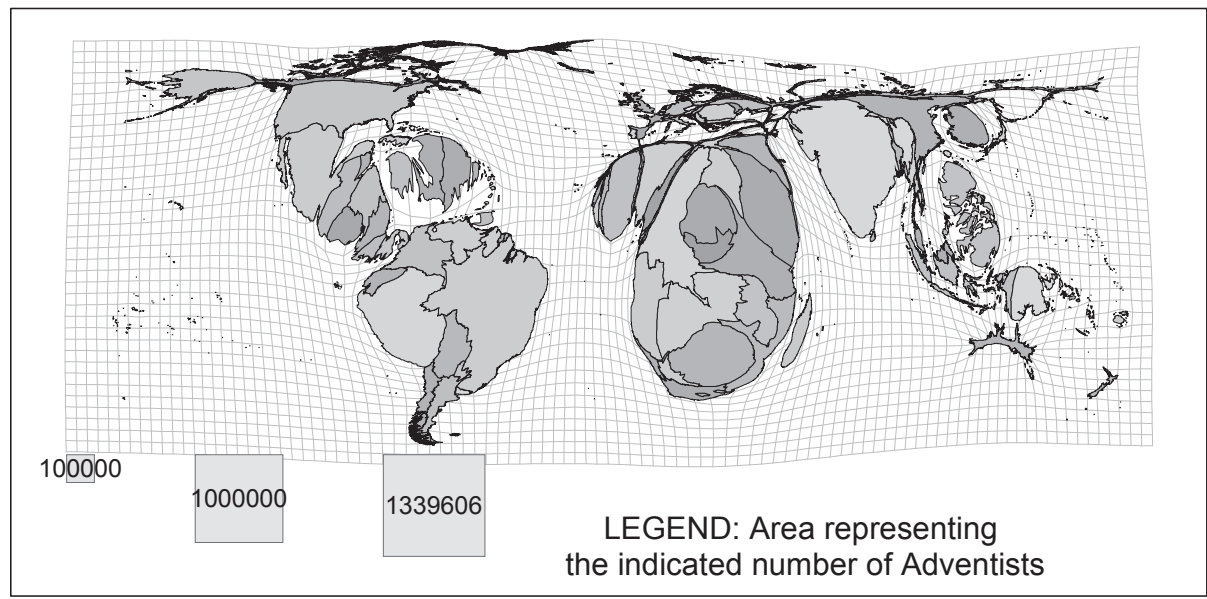

Fig. 2 Membership in the Seventh-day Adventist Church by country 2007 Source: $145^{\text {th }}$ Annual Statistical Report - 2007.

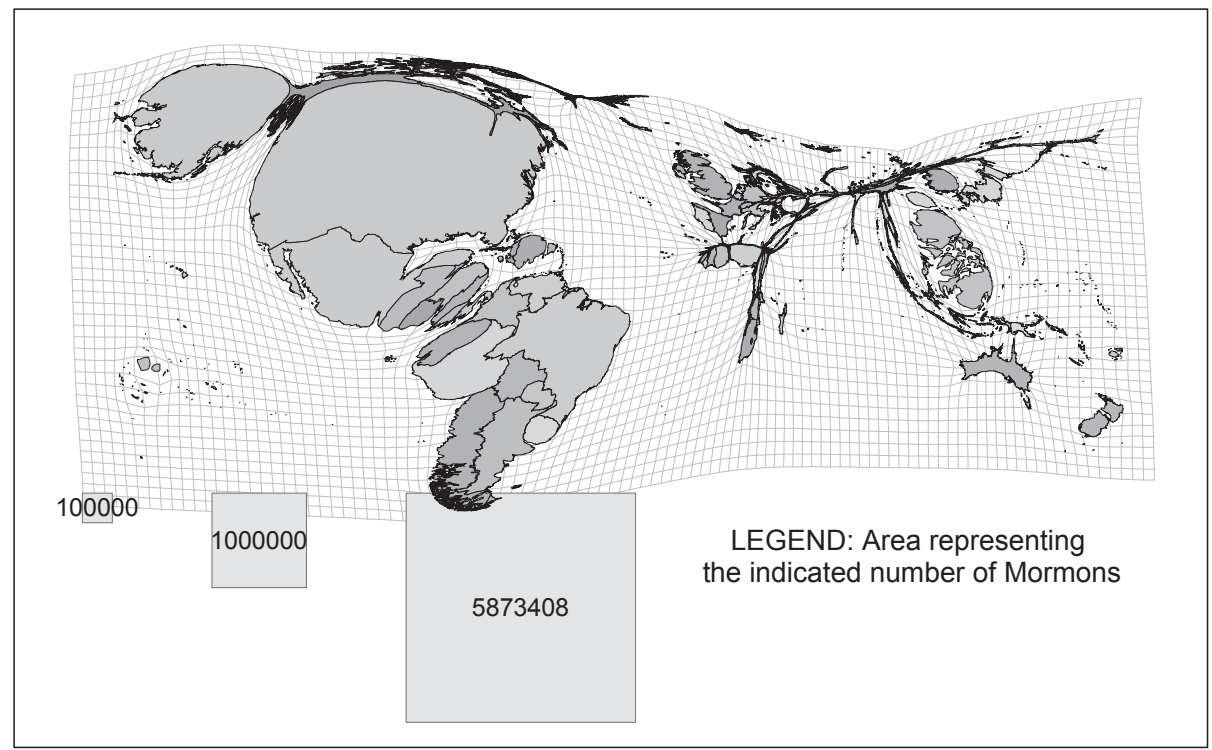

Fig. 3 Membership in the Church of Jesus Christ of Latter-day Saints by country 2007 Source: www.newsroom.lds.org 
Mormons, who, in contrast, have a stronger relative position in several countries in North and South America, the Pacific Ocean and Western Europe. In general, the global distribution of Mormons seems to more closely resemble a contact diffusion model, radiating out from the organization's headquarters in Utah. This trend is even more evident if membership data for the individual states or counties of the United States of America are viewed separately (see Otterstrom 2008). Both Utah (1,823,613 Mormons) and California (749,490 Mormons) would rank among the top five political territories, in terms of overall membership (see Table 2).

Tab. 2 Largest Adventist and Mormon populations by country 2007

\begin{tabular}{|c|c|c|c|c|c|}
\hline \multicolumn{3}{|c|}{ Largest populations of Adventists by country } & \multicolumn{3}{|c|}{ Largest populations of Mormons by country } \\
\hline Country & Adventists & $\begin{array}{c}\text { Percent of total } \\
\text { church membership }\end{array}$ & Country & Mormons & $\begin{array}{c}\text { Percent of total } \\
\text { church membership }\end{array}$ \\
\hline India & $1,339,606$ & $9 \%$ & United States & $5,873,478$ & $45 \%$ \\
\hline Brazil & $1,331,282$ & $9 \%$ & Mexico & $1,121,893$ & $9 \%$ \\
\hline United States & $1,000,578$ & $6 \%$ & Brazil & $1,019,153$ & $8 \%$ \\
\hline Peru & 769,980 & $5 \%$ & Philippines & 594,655 & $5 \%$ \\
\hline Kenya & 609,934 & $4 \%$ & Chile & 548,743 & $4 \%$ \\
\hline
\end{tabular}

Source: $145^{\text {th }}$ Annual Statistical Report -2007 and www.newsroom.lds.org

Table 2 lists the largest five countries, in terms of numbers of Adventists and Mormons, along with the portion of all adherents (worldwide) to the two respective churches, residing in each of these countries. The dominance of the United States of America, for instance, as a center for Mormonism is clearly evident in its $45 \%$ share in the church's overall membership. Adventists on the other hand are more evenly distributed internationally with India and Brazil both holding a 9\% share in the church's worldwide membership. It is interesting to note the appearance of the USA - as the place of origin - and, more especially, Brazil - as a center of growth in each of the churches' top five lists.

Both Adventists and Mormons have been very active in seeking converts from the beginnings of their respective movements. Consequently, understanding the history of missionary work and global expansion within the two churches, especially any unique restrictions, strategies or advantages in spreading their missionary messages, is very helpful in explaining the present-day distribution expressed above (Figures 2 and 3).

\section{Rapid worldwide expansion of Adventists}

Missionaries were spreading the message of Adventism even before the General Conference of Seventh-day Adventists was officially founded in 1863. As early as 1864, Michael Belina Czechowski, previously a Catholic minister, was already 
preaching Seventh-day Adventism in Europe (Drejnar 2008). The first official missionary was sent abroad - to Switzerland - in 1874.

In general, it can be said that Adventist missionary efforts focused, and continue to focus, on people throughout the world, regardless of race, religion or socioeconomic status. It appears, however, that over time, Adventist missionaries found more success and, consequently, expended more effort among populations of economically disadvantaged people, especially in less developed areas. The cartogram in Figure 2 corroborates this notion.

While the reasons for developments, leading to the present-day distribution of Adventists, are somewhat difficult to pinpoint, a possible explanation could be the humanitarian service of Adventist missionaries and the church's focus on development and aid programs. The Adventist Development and Relief Agency (ADRA, see www.adra.org) is the Seventh-day Adventist Church's flagship organization in providing such assistance. ADRA is a modern manifestation of the church's history of offering aid and education to diverse populations.

One of the first steps that Adventist missionaries took when settling into many of the countries they entered, especially in underdeveloped regions, was the establishment of schools. These included elementary schools, schools for girls, schools for boys, intermediate or secondary schools and, as Adventist presence grew, even colleges and universities. To illustrate, in 1900 at the leading edge of several decades of rapid missionary expansion, the church operated 220 primary schools. By 1930 , the number of Adventist primary schools had increased to 2,077; by 1950, to 4,277 (145 ${ }^{\text {th }}$ Annual Statistical Report - 2007).

Adventist missionary efforts in Papua New Guinea followed this school establishment model. In 1908, not long after initiating missionary work in the country on a permanent basis, a plantation with an accompanying school was founded. As the local people became aware of these missionaries and saw the benefits the school provided, they gradually became interested in having a second Adventist school. In spite of - or, perhaps, because of - these slow beginnings, from 1928 to 1934, Adventists saw rapid growth through the establishment of schools. In 1934, there were still less than 50 baptized members of the Seventh-day Adventist Church among Papua New Guineans. Seeds planted through the operating schools, however, soon bore fruit and, in 1940, there were 68 Adventist-operated schools and more than 2,000 Adventists in Papua New Guinea ( $78^{\text {th }}$ Annual Statistical Report - 1940). Growth continued, both in terms of church membership and schools. In 1984, Pacific Adventist University was established in New Guinea as a college; it acquired university status in 1997. (http://adventist.org.au) At the end of 2007, Adventist church membership in Papua New Guinea stood at 237,220, representing more than four percent of the country's total population ( $145^{\text {th }}$ Annual Statistical Report - 2007).

New Guinea is only one example from many. Adventist missionaries were very quick to spread, quite literally "into all the world" (Holy Bible, Luke 16:15), with their message. After Europe, they entered Australia and several Pacific island nations in the 1880's; Russia, in 1886; India, in 1893; Western and Southern Africa, 
in 1894; and China and Japan, in 1896. By the end of the nineteenth century, congregations had been established in many countries and the movement was quickly becoming a worldwide church. (www.adventist.org.in, http://adventist.org.au, www.adventist.org)

Early successes of Adventist missionaries in establishing congregations and encouraging growth in both China and India have had far-reaching effects. By 1949, when the Communist Party of China established the People's Republic of China and officially outlawed the Seventh-day Adventist Church, there were more than 23,000 Adventists in China. This foundation allowed the church to maintain an underground organization and, as of 2005, more than 300,000 Adventists were reported to live in China. Similarly, in India, the Adventist Church was able to grow enough among the native population, especially early in the 1900s, before India became independent from British rule, to weather significant opposition from the Hindu majority and to continue to grow in recent years. (Land 2005)

To understand the global distribution of Adventists today, it is necessary to take the organizational structure of the Seventh-day Adventist Church into consideration. The following brief outline is published on the worldwide church's official website (http://www.adventist.org/world_church/facts_and_figures/structure/index.html.en):

The Seventh-day Adventist Church is organized with a representative form of church government. This means authority in the Church comes from the membership of local churches. Executive responsibility is given to representative bodies and officers to govern the Church. Four levels of Church structure lead from the individual believer to the worldwide Church organization:

1. The local church made up of individual believers.

2. The local conference, or local field/mission, made up of a number of local churches in a state, province, or territory.

3. The union conference, or union field/mission, made up of conferences or fields within a larger territory (often a grouping of states or a whole country).

4. The General Conference represents the worldwide expression of the Seventhday Adventist Church. Its constituent membership is defined in the Constitution of the General Conference. To facilitate its worldwide activity, the General Conference has established regional offices, known as divisions of the General Conference, which have been assigned, by action of the General Conference Executive Committee at Annual Councils, general administrative oversight responsibilities for designated groups of unions and other church units within specific geographical areas.

Each level is "representative," that is it reflects a democratic process of formation and election. Local churches elect their own officers and church boards by majority voting. Churches elect delegates to the conferences which meet "in session" every two or three years. Executive authority between sessions is exercised by the Conference Executive Committee and the executive officers (normally President, Secretary and Treasurer), all of whom are elected by the session. 
To take this comparison further, all three of these sub-international levels of Adventist organization (levels 1-3 above) are present in Czechia, or rather in Czecho-Slovakia. The Czecho-Slovakian Union Conference (level 3) is divided into three conferences, two of which - the Bohemian Conference and the Moravia-Silesian Conference (level 2) - comprise the present territory of Czechia.

From my own observations, it appears that Adventist congregations in Czechia have relatively more local autonomy (i.e. less centrally applied leadership) than comparable congregations of Mormons in Czechia (see the discussion below on the organizational structure of the LDS Church). This higher degree of local autonomy - expressed primarily through less emphasis on vertical communication and coordination within the organization - could help explain the more globally dispersed and less-concentric distribution of Adventists, in comparison with the distribution of Mormons due to the simple fact that less central directives, communications and controls could contribute to local independence and creativity, which could, in turn, be more flexible to local needs.

\section{Mormon Zionism and its concentric legacy}

The Church of Jesus Christ of Latter-day Saints was also quick to begin spreading its missionary message. Earliest missionary efforts focused on the United States and the British Isles and the cartogram in Figure 3 shows that this early focus is still reflected in current membership rates. Mormon missionary work soon expanded into other parts of Europe; however, during these early years the message of Mormonism included a call to "gather to Zion." With a doctrine-based practice that lends itself to comparison with Jewish Zionism, new converts to the Church of Jesus Christ were encouraged to immigrate to the United States to join with other Mormons in building a "New Jerusalem" on the American Continent (The Articles of Faith, no. 10). This practice played a significant role in Mormon history and in the subsequent development and diffusion of the church. (Our Heritage: A Brief History of The Church of Jesus Christ of Latter-day Saints 1996)

Their strong sense of community, combined with this doctrine of gathering, only encouraged the suspicion and enmity that Mormons were already facing from neighboring communities, due to their position as a new and different religious movement. They resettled en masse to Kirtland, Ohio (near Cleveland) in the early 1830 s, from where they were "encouraged" to move on, settling in Missouri. By 1838, Mormons' Missouri neighbors decided they had had enough and they forcefully expelled the church and its members - with their governor's blessing - from the state of Missouri. Throughout these difficult times, new converts to Mormonism, from other states in America as well as from Western and Northern Europe, continued to migrate to join with fellow Mormons, wherever they happened to be. (Our Heritage 1996) 
After Missouri, the Mormons established the city of Nauvoo on a bend in the Mississippi River. This city held the distinction of being the largest city in Illinois for a time, before Chicago experienced its booming growth. It was not long, however, before surrounding communities in Illinois expressed their opposition to the growing Mormon presence, which by this time possessed considerable - and growing - political power and societal influence. In June 1844, an armed mob murdered Joseph Smith and his brother Hyrum in a Carthage, Illinois jailhouse, where they were awaiting trial on trumped up charges. By February 1846, most Mormons had been forced out of (or had promised to soon leave) Illinois and they began making their way west, in search of a place, where they could establish themselves permanently and peacefully. They chose to make the Salt Lake Valley at the foot of the Wasatch Mountains, in what is now Utah, the center of their "Zion" and, consequently, the target for a growing number of Mormon immigrants, primarily from the eastern United States and from Europe. (Our Heritage 1996)

In 1911, the First Presidency, the supreme governing body of the Church of Jesus Christ of Latter-day Saints, issued the following proclamation. "It is desirable that our people shall remain in their native lands and form congregations of a permanent character to aid in the work of proselyting." (Our Heritage 1996, p. 105) This marked a turning point in the diffusion of Mormonism and the development of the global distribution of Mormons. While it is true that not all Mormons relocated to the American West, previous to this proclamation, the fact that many did is well documented (see Our Heritage) and helps explain the global distribution of Mormons, as portrayed in Figure 3. The cartogram shows the clear dominance of the United States of America.

As described above, Mormons believe in The Book of Mormon as an additional book of scripture, containing the writings of prophets who lived in the Americas for several hundred years before and after the birth of Jesus Christ (approximately 600 B.C. to 400 A.D.). The book also records a visit that Christ himself made to these people in the Americas, after his death and resurrection in Jerusalem. This focus on America (both North and South America) as a "second holy land" could conceivably contribute to the popularity of the Mormon message in the Western Hemisphere, especially among Native Americans and Pacific Islanders, who, according to Mormon tradition, are descendents of the groups of people described in The Book of Mormon.

Another factor, effecting the establishment of Mormonism worldwide, arose out of a restriction concerning those who could hold the priesthood and, thereby, officiate in church ordinances and fill leadership roles. It was not until 1978 that the privilege of holding the priesthood was extended to "every faithful, worthy man in the Church" of Jesus Christ of Latter-day Saints (Doctrine and Covenants p. 294). Previous to this official declaration from the First Presidency, men of African decent had not been eligible to hold the priesthood, a restriction that had made missionary work throughout most of Africa impractical, at best. While significant 
growth in the number of Mormons in Africa has happened since 1978, the effects of this relatively late start can be seen in Figure 3.

Additional interesting characteristics that have played (and continue to play) a significant role in the way Mormonism has spread include the unique Mormon missionary program and the centralized organization of the Church of Jesus Christ of Latter-day Saints. Young Mormons, primarily between the ages of 19 and 25 years of age, are strongly encouraged to serve as full-time missionaries. Interested, eligible individuals fill in a paper application and go through an interview process with local Mormon leaders. Application materials are then sent to church headquarters in Salt Lake City and within a matter of weeks a "mission call" is issued. In 1997, for example, I completed this process and received a "mission call" to serve for two years in the Czech Prague Mission, which includes all of Czechia and Slovakia. Mormons view these mission calls as the result of divine inspiration channeled through the leaders responsible for deciding where prospective missionaries will serve. Mormon missionaries always work in pairs and wear black nametags. Their primary objective is to provide others with an opportunity to learn about the "message of the restoration", which in essence is based upon Joseph Smith's role as a modern prophet, the Book of Mormon as a book of scripture and the existence of a living prophet today. These missionaries generally serve for eighteen months or two years and pay their own way.

The Church of Jesus Christ of Latter-day Saints is also characterized by a centralized organizational scheme, with a structured hierarchy leading up to the president of the church, who along with his two counselors, comprise the First Presidency. According to Mormon beliefs, the president of the church is a prophet, receiving guidance and inspiration, concerning how to direct the Church of Jesus Christ, from Christ himself. In addition to these three men (the First Presidency), Mormons look to a Quorum of Twelve Apostles - twelve other men, "called" by inspiration to serve as Apostles until they die - for what they view as inspired leadership for the entire world. Moving down the vertical structure, Mormons also receive guidance from five Quorums of "Seventies" - general and regional authorities - and, ultimately and more intimately, from local leaders.

Among other things, this organization means that significant vertical relations exist to monitor both compliance with central directives and consistency concerning the doctrines and practices emphasized throughout the global Mormon organization. The church's missionary program facilitates ongoing exchanges and interactions between lay members and full-time missionaries from diverse parts of the world (especially from areas that are home to many Mormons, i.e. North America), further encouraging feelings of cross-cultural unity and consistent group practices and behaviors. It is clear that these two additional characteristics of the Mormon faith - its central organization scheme and its missionary program - contribute to a high degree of acculturation, which aids in explaining relatively higher concentrations of Mormons in areas with a western, or westernoriented, culture. 
Another way to examine the distribution of Adventists and Mormons is to look at the position of the two respective churches, in terms of the portion of a political state's population that is comprised, respectively, of Adventists or Mormons. Using the same data as above (provided by the two churches in question and by the CIA World Factbook), I have calculated the percent of national populations that are Adventist or Mormon. I will refer to this statistic as a measure of the position of the two respective churches in various national societies.

Interestingly, both churches have significantly strong positions on several islands (for Mormons the highest percentages are located in the South Pacific, for Adventists in the Caribbean Sea), where total populations are often quite small. Tables 3 and 4 show the ten highest overall national percentages of Adventists and Mormons, respectively, along with total country populations.

Tab. 3 Ten highest percentages of Adventists within total country populations

\begin{tabular}{|l|c|c|c|c|}
\hline COUNTRY & REGION & POPULATION & ADVENTIST & \% \\
\hline Pitcairn Island & South Pacific & 48 & 22 & 45.83 \\
\hline Grenada & Caribbean & 89,971 & 12,369 & 13.75 \\
\hline Montserrat & Caribbean & 9,538 & 1,159 & 12.15 \\
\hline Antigua and Barbuda & Caribbean & 69,481 & 7,927 & 11.41 \\
\hline St. Vincent and G. & Caribbean & 118,149 & 13,296 & 11.25 \\
\hline Belize & Central America & 294,385 & 31,215 & 10.60 \\
\hline Dominica & Caribbean & 72,386 & 6,543 & 9.04 \\
\hline Saint Lucia & Caribbean & 170,649 & 14,629 & 8.57 \\
\hline Jamaica & Caribbean & $2,780,132$ & 229,595 & 8.26 \\
\hline Cayman Islands & Caribbean & 46,600 & 3,692 & 7.92 \\
\hline
\end{tabular}

Source: $145^{\text {th }}$ Annual Statistical Report -2007 , CIA World Factbook.

Tab. 4 Ten highest percentages of Mormons within total country populations

\begin{tabular}{|l|c|c|c|c|}
\hline COUNTRY & REGION & POPULATION & MORMON & \multicolumn{1}{c|}{$\%$} \\
\hline Tonga & South Pacific & 116,921 & 54,281 & 46.43 \\
\hline Samoa & South Pacific & 214,265 & 66,249 & 30.92 \\
\hline American Samoa & South Pacific & 57,663 & 14,514 & 25.17 \\
\hline Niue & South Pacific & 1,492 & 253 & 16.96 \\
\hline Kiribati & South Pacific & 107,817 & 12,446 & 11.54 \\
\hline Cook Islands & South Pacific & 21,750 & 1,803 & 8.29 \\
\hline Marshall Islands & South Pacific & 61,815 & 4,623 & 7.48 \\
\hline French Polynesia & South Pacific & 278,963 & 19,711 & 7.07 \\
\hline Micronesia & South Pacific & 107,862 & 3,754 & 3.48 \\
\hline Chile & South America & $16,284,741$ & 548,743 & 3.37 \\
\hline
\end{tabular}

Source: www.newsroom.lds.org, CIA World Factbook. 
Tables 5 and 6 disclose the same indicator for the highest ten countries and for the two respective churches, after removing all countries with less than one million inhabitants. Considering these larger populations, a concentration of Adventists in parts of Africa and South America, in addition to the Caribbean, becomes evident. Countries in the Americas - both North and South America - dominate the list of large Mormon percentages in more populated countries.

Tab. 5 Ten highest percentages of Adventists within total country populations for countries with more than one million inhabitants

\begin{tabular}{|l|c|c|c|c|}
\hline COUNTRY & REGION & POPULATION & ADVENTIST & \% \\
\hline Jamaica & Caribbean & $2,780,132$ & 229,595 & 8.26 \\
\hline Trinidad and Tobago & Caribbean & $1,056,608$ & 61,273 & 5.80 \\
\hline Zambia & Southern Africa & $11,477,447$ & 567,881 & 4.95 \\
\hline Zimbabwe & Southern Africa & $12,311,143$ & 534,801 & 4.34 \\
\hline Rwanda & Eastern Africa & $9,907,509$ & 423,358 & 4.27 \\
\hline Papua New Guinea & South Pacific & $5,795,887$ & 237,220 & 4.09 \\
\hline Haiti & Caribbean & $8,706,497$ & 315,538 & 3.62 \\
\hline Peru & South America & $28,674,757$ & 769,980 & 2.69 \\
\hline Angola & Southern Africa & $12,263,596$ & 327,078 & 2.67 \\
\hline Dominican Republic & Caribbean & $9,365,818$ & 242,084 & 2.58 \\
\hline
\end{tabular}

Source: $145^{\text {th }}$ Annual Statistical Report - 2007, CIA World Factbook.

Tab. 6 Ten highest percentages of Mormons within total country populations for countries with more than one million inhabitants

\begin{tabular}{|l|c|c|c|c|}
\hline COUNTRY & REGION & POPULATION & MORMON & $\mathbf{\%}$ \\
\hline Chile & South America & $16,284,741$ & 548,743 & 3.37 \\
\hline USA & North America & $301,139,947$ & $5,873,408$ & 1.95 \\
\hline Bolivia & South America & $9,119,152$ & 158,427 & 1.74 \\
\hline Honduras & Central America & $7,483,763$ & 125,606 & 1.68 \\
\hline Guatemala & Central America & $12,728,111$ & 210,101 & 1.65 \\
\hline Peru & South America & $28,674,757$ & 448,903 & 1.57 \\
\hline El Salvador & Central America & $6,948,073$ & 98,575 & 1.42 \\
\hline Ecuador & South America & $13,755,680$ & 181,463 & 1.32 \\
\hline Panama & Central America & $3,242,173$ & 42,606 & 1.31 \\
\hline Dominican Republic & Caribbean & $9,365,818$ & 106,243 & 1.13 \\
\hline
\end{tabular}

Source: www.newsroom.lds.org, CIA World Factbook.

\section{Conclusion}

It is clear that the simplistic null-hypothesis, proposed above, can be rejected. Significant regional differences exist both in the distribution of Adventists and Mormons throughout the world, as well as in the portions of adherents to the two churches in diverse countries and regions. Both churches' distributions differ sig- 
nificantly from the distribution of the overall population. Adventists are relatively more evenly distributed throughout the world, while Mormons show a strong concentric distribution, focused on the Mormon cultural region in the western United States.

The apparent absence of internal limitations, governing international expansion, along with a higher degree of local autonomy is helpful in explaining the relatively more balanced worldwide distribution of Adventists. Additionally, higher concentrations of Adventists can be found in many less-developed areas, indicating a correlation with the strong Adventist emphasis on humanitarian aid. In contrast, the concentric distribution of Mormons on a global scale can be attributed in part to the historical practice of "Mormon Zionism" and to the existence of strong cultural norms, expressed and enforced through this church's hierarchical structure and frequent cross-cultural exchanges. The effects of limitations on missionary work, past or present, can also be seen in the current distribution of Mormons throughout the world.

The comparative nature of this research - examining two similar Christian denominations - makes it unique and valuable both in terms of the scientific research of religion as well as in terms of geographic inquiry into cultural diffusion. The growth and continued activity of these two religious organizations confirm the ongoing significance of religion as an "axis of identity" (Brace, Bailey and Harvey 2006). In addition, the international diffusion of religious groups also provides an interesting looking glass for observing processes of globalization and cultural change. Further comparative research into the growth and distribution of various religious groups (especially including non-Christian groups) would be a welcome addition to contemporary social science knowledge.

\section{Acknowledegements}

This research was implemented as part research project GA AV No. IAA701110701, entitled: "The Differentiation of Changes in Czechia's Religious Landscape during the Transformation Period".

\section{Sources}

(1941): $78^{\text {th }}$ Annual Statistical Report - 1940. General Conference of Seventh-day Adventists, Silver Spring Maryland, USA.

(2008): $145^{\text {th }}$ Annual Statistical Report - 2007. General Conference of Seventh-day Adventists, Silver Spring Maryland, USA.

BARFORD, A. and DORLING, D. (2007): A new view of the world: A map a day, for every day of the year. GeoInformatics, 10, 3, pp. 14-16.

BRACE, C., BAILEY, A. and HARVEY, D. (2006): Religion, place and space: a framework for investigating historical geographies of religious identities and communities. Progress in Human Geography, 30, 1, pp. $28-43$. 
CROSS, W. (1950): The Burned-over District: the social and intellectual history of enthusiastic religion in western New York, 1800-1850. Cornell University Press, Ithaca, New York, 383 pp.

(1981): The Doctrine and Covenants. The Church of Jesus Christ of Latter-day Saints, Salt Lake City, 297 pp.

DREJNAR, J. (2008): Boži stopy na cestě cirkve: počátky a vývoj Církve adventistů sedmého dne v Čechách. Luxpress, Prague. 117 pp.

DUNN, E. (1996): Money, morality and modes of civil society among American Mormons. In Dunn, E. and Hann, C., ed.: Civil Society: Challenging western models. Routledge, pp. 27-49.

GASTNER, M. and NEWMAN, M. (2004): Diffusion-based method for producing density-equalizing maps. Proceedings of the National Academy of Sciences of the United States of America, 101, 20, pp. 7499-7504.

HENKEL, R. (2006): Definition von Religion und Religionstheorien - was kann die Religionsgeographie aus der Diskussion in Religionssoziologie und Religionswissenschaft lernen? Acta Universitatis Carolinae Geographica, XLI, 1-2, pp. 77-90.

IANNACCONE, L. and STARK, R. (1997): Why the Jehovah's Witnesses grow so rapidly: a theoretical application. Journal of Contemporary Religion, 12, 2, pp. 133-157.

IANNACCONE, L. (1997): Rational choice: Framework for the scientific study of religion. In Young, L., ed.: Rational Choice Theory and Religion: summary and assessment, pp. 25-44.

IANNACCONE, L. (1998): Introduction to the economics of religion. Journal of Economic Literature, XXXVI, pp. 1465-1496.

KONG, L. (2001): Mapping new geographies of religion: politics and poetics in modernity. Progress in Human Geography, 25, 2, pp. 211-233.

LAND, G. (2005): Historical Dictionary of Seventh-day Adventists. Scarecrow Press. 419 pp.

MCBRIDE, M. (2007): Club Mormon: free-riders, monitoring and exclusion in the LDS Church. Rationality and Society, 19, 4, pp. 395-424.

OTTERSTROM, S. (1994): The International Diffusion of the Mormon Church. MS Thesis, Brigham Young University, $119 \mathrm{pp}$.

OTTERSTROM, S. (2008): Divergent growth of the Church of Jesus Christ of Latter-day Saints in the United States, 1990-2004: Diaspora, gathering, and the east-west divide. Population, Space and Place, 14, pp. 231-235.

(1996): Our Heritage: A Brief History of the Church of Jesus Christ of Latter-day Saints. The Church of Jesus Christ of Latter-day Saints, Salt Lake City, 152 pp.

(1981): The Pearl of Great Price. The Church of Jesus Christ of Latter-day Saints, Salt Lake City, 61 pp.

ROSTEN, L. (Ed.) (1963): Religions in America. New York: Simon and Schuster, 414 pp.

SLAVÍČEK, J., KITTNAR, O., FRASER, G., MEDOVÁ, E., KONEČNÁ, J., ŽIŽKA, R. and DOHNALOVÁ, A. (2008): Lifestyle decreases risk factors for cardiovascular diseases. Central European Journal of Public Health, 16, 4, pp. 161-164.

(2008): Statistical Report: $178^{\text {th }}$ Annual General Conference of the Church of Jesus Christ of Latter-day Saints (accessed 3. 2. 2009 at: http://lds.org/conference/sessions/display/0,5239,23-1-851,00.html).

VANDEMAN, G. (1986): What I Like About... Lutherans, Baptists, Methodists, Charismatics, Catholics, our Jewish Friends and Adventists. Pacific Press: Boise, Idaho, USA, 108 pp.

VOJTÍŠEK, Z. (2007): Nová náboženská hnutí a jak jim porozumět. Beta Books, Praha, 210 pp.

WARF, B. and WINSBERG, M. (2008): The geography of religious diversity in the United States. The Professional Geographer, 60, 3, pp. 413-424.

ZELINSKY, W. (2001): The uniqueness of the American religious landscape. Geographical Review, 91, 3, pp. 565-585.

Seventh-day Adventist Church (worldwide organization) www.adventist.org (12. 2008 to 4. 2009)

- ADRA: www.adra.org (5. 2. 2009)

- Ellen G. White Estate: www.whiteestate.org and http://www.whiteestate.org/pathways/pioneers.asp (25. 2. 2009)

- History: http://www.adventist.org/world_church/facts_and_figures/history/index.html.en (6. 2. 2009)

- Organizational structure: http://www.adventist.org/world_church/facts_and_figures/structure/index. html.en (24. 4. 2009)

- Seventh-day Adventist Church South Pacific: http://adventist.org.au (6. 2. 2009)

- Southern Asia Division of Seventh-day Adventists: www.adventist.org.in (6. 2. 2009)

Church of Jesus Christ of Latter-day Saints: www.lds.org (12. 2008 to 4. 2009)

- Newsroom (statistical information): www.newsroom.lds.org (1.2009 to 4. 2009) 
- The Articles of Faith of the Church of Jesus Christ of Latter-day Saints: http://scriptures.lds.org/en/a of $\mathrm{f} / 1$ (6. 2. 2009)

CIA World Factbook 2008 (data for 2007): https://www.cia.gov/library/publications/the-world-factbook/ (12. 2008 to 4.2009$)$

\section{Résumé}

\section{Rozmístění adventistů a mormonů ve světě v roce 2007}

Článek v celosvětovém měřítku zkoumá rozdíly v prostorovém rozmístění dvou relativně mladých a v mnoha ohledech podobných církví, Církve adventistů sedmého dne a Církve Ježíše Krista svatých posledních dnů. Článek vychází ze dvou směrů výzkumných otázek: 1. Jak se vyvíjela a širríla hnutí adventistů a mormonů od svých počátků do podoby mezinárodních náboženských společenství? (proces difuze) a Jak se liší aktuální rozmístění adventistů a mormonů ve světě? 2. Které mechanismy utvářely rozdíly v rozmístění př́slušníků těchto dvou církví?

Obě církve byly založeny v severovýchodních státech USA během 19. století. Postupně se rozšíriily a ke konci roku 2007 evidovaly podobný počet členů po celém světě (Adventisté: 15660 347, Mormoni: 13193 999). V obou př́ípadech se jedná o křest’anské církve, které zdůrazňují mj. druhý příchod Ježíše Krista a zdravou výživu.

Vzhledem ke sdíleným počátkům a současné velikosti církví, předpokládá nulová hypotéza u obou církví podobný prostorový vzorec. Následující analýza srovnává rozmístění adventistů a mormonů ve světě.

Autor využívá kartogramy, které mění velikost územních jednotek na základě daného jevu (tzv. densityequalizing maps), $v$ tomto př́ípadě podílu adventistů či mormonů na populaci jednotlivých států světa. Prostorová distribuce adventistů je poměrně rovnoměrná, $v$ př́ípadě mormonů sledujeme koncentrickou distribuci s centrem na západě Spojených států, kde církev sídlí.

Vysvětlení odlišností v absolutním i relativním zastoupení adventistů a mormonů v jednotlivých zemích je třeba hledat $\mathrm{v}$ rozdílné historii církví, uplatňovaných politikách a praktikách, které ovlivnily šíření jejich myšlenek. Významným př́íladem je tzv. mormonský sionismus, kde mormonští vůdcové vyzvali všechny mormony k tomu, aby se přistěhovali do Údolí solného jezera v Utahy a vybudovali tam silné komunity. Tato výzva, která platila až do roku 1911, hrála velkou roli v difuzi Církve Ježíše Krista svatých posledních dnů.

Mgr. Daniel Reeves Charles University in Prague

Faculty of Science

Department of Social Geography and Regional Development

Albertov 6

12843 Prague 2

Czech Republic 